\title{
PEMBELAJARAN MENULIS KARANGAN DESKRIPSI MENGGUNAKAN MEDIA GAMBAR
}

\author{
Hajratul Aswat ${ }^{1)}$, Meri Basri ${ }^{2)}$, Muh.Ismail Kaleppon ${ }^{3)}$, Aswandi Sofyan ${ }^{4)}$ \\ ${ }^{1,2,3,4)}$ Program Studi Pendidikan Bahasa dan Sastra Indonesia \\ Fakultas Sastra, Universitas Muslim Indonesia \\ Email: hajra1097@gmail.com
}

\begin{abstract}
Abstrak: Keterampilan menulis merupakan kegiatan yang tidak terpisahkan dari kegiatan belajar mengajar siswa di sekolah. Kegiatan menulis menjadikan siswa aktif dalam kegiatan pembelajaran dan merangsang keterampilan siswa dalam merangkai kata. Akan tetapi, dalam penerapannya banyak orang mengalami kesulitan untuk membiasakan siswa belajar menulis. Penyebabnya adalah kesalahan dalam hal pengaran yang terlalu kaku sehingga menimbulkan kesan bahwa menulis itu sulit. Mereka juga kesulitan dalam menyusun kalimat, terbatasnya kosa kata yang dimiliki, dan kurangnya imajinasi atau kreativitas untuk berfikir saat menulis. Dengan melihat hal-hal tersebut, maka diperlukan sebuah cara atau solusi untuk mengatasi permasalahan-permasalahan tersebut. Tidak dapat dipungkiri bahwa kemampuan menulis tidaklah datang secara otomatis tetapi harus melalui latihan, praktik yang banyak, dan teratur. Pembelajaran menulis di sekolah sebagai wadah untuk mengembangkan potensi siswa dalam hal tulis-menulis pada diri siswa. Guru, dalam hal ini tidak hanya berperan untuk mengembangkan pengetahuan serta keterampilan, tetapi juga nilai yang berkenaan dengan keterampilan menulis serta menumbuhkan budaya tulis-menulis pada diri siswa. Tujuan keterampilan menulis mendeskripsikan peningkatan proses pembelajaran kemanpuan menulis, salah satunya menulis karangan deskripsi pada pembelajaran bahasa Indonesia. Karangan deskripsi merupakan salah satu langkah mudah seseorang dalam menulis karena karangan deskripsi akan mengolah pola pikir siswa terhadap objek yang dilihatnya, siswa dilatih menggambarkan objek yang dilihatnya, kemudian dituangkan dalam bentuk tulisan. Dalam proses pembelajaran menulis karangan deskripsi, seorang guru dapat menggunakan media gambar. Menggunakan media gambar dapat meningkatkan kreativitas dan imajinasi siswa serta melatih daya ingat siswa sehingga kemanpuan siswa dalam menulis dapat meningkat, hingga sekaligus melatih kemampuan berbicara dan menyimak.
\end{abstract}

Kata kunci: Pembelajaran menulis, karangan deskripsi, media gambar

\section{PENDAHULUAN}

Masyarakat modern seperti sekarang ini dikenal dua macam cara berkomunikasi, yaitu komunikasi secara langsung dan komunikasi secara tidak langsung. Kegiatan berbicara dan mendengarkan (menyimak), merupakan komunikasi secara langsung, sedangkan kegiatan menulis dan membaca merupakan komunikasi tidak langsung.

Keterampilan menulis sebagai salah satu cara dari empat keterampilan berbahasa, mempunyai peranan yang penting dalam kehidupan manusia. Dengan menulis seseorang dapat mengungkapkan pikiran dan gagasan untuk mencapai maksud dan tujuannya.

Mengarang pada prinsipnya adalah bercerita tentang sesuatu yang ada pada angan-angan penceritaan itu dapat dituangkan dalam bentuk lisan maupun tulisan. Setiap manusia semuanya diciptakan sebagai pengarang. Menuangkan buah pikiran secara teratur dan terorganisasi ke dalam tulisan tidaklah mudah. Banyak orang yang 
pandai berbicara atau berpidato, tetapi mereka masih kurang mampu menuangkan gagasannya ke dalam bentuk bahasa tulisan. Maka untuk bisa mengarang dengan baik, seseorang harus mempunyai kemampuan untuk menulis. Kemampuan menulis dapat dicapai melalui proses belajar dan berlatih.

Namun demikian ternyata banyak orang yang kekurangan ide atau bisa jadi idenya banyak tetapi tetap saja kesulitan dalam menulis. Dunia informasi telah berkembang demikian pesat, dengan pesatnya perkembangan dunia informasi khususnya perkembangan kegiatan tulis menulis tentu menuntut kita agar mengembangkan tradisi menulis. Tradisi menulis dapat diartikan sebagai suatu kebiasaan untuk menyatakan gagasan atau pendapat secara tertulis.

Untuk mengatasi kendala sebagaimana dipaparkan di atas, salah satu upaya yang dilakukan yaitu dengan menggunakan media gambar, agar mengurangi kejenuhan pada pembelajaran menulis yang pada akhirnya siswa akan terbiasa untuk mengungkapkan isi pikiran dan menggambarkan sesuatu secara runtut dan sistematis. Sekarang, gambar telah populer dalam dunia pendidikan dan merupakan alat peraga yang disadari pentingnya untuk memperjelas pemahaman peserta didik, menghindari salah pengertian antara guru dengan peserta didik, dan untuk menarik minat serta perhatian peserta didik. Untuk meningkatkan keterampilan menulis peserta didik, maka dilakukanlah proses Pembelajaran Menulis Karangan Deskripsi Menggunakan Media Gambar, sebagai langkah awal dalam proses menulis dengan mengasah pola pikir peserta didik melalui gambar yang dilihatnya secara langsung tanpa harus berpikir kritis dengan membayangkan sesuatu yang belum pernah dilihatnya sama sekali. Sehingga mampu menggunakan dan memilih kata dalam menuangkan buah pikirannya.

\section{PEMBAHASAN}

\section{Keterampilan Menulis}

Istilah menulis berasal dari kata tulis. Dalam Kamus Besar Bahasa Indonesia, tulis mengandung arti ada huruf (angka dan sebagainya) yang dibuat (digurat dan sebagainya) dengan pena (pensil, cat, dan sebagainya). Menulis adalah menurunkan atau melukiskan lambang-lambang grafik yang menggambarkan suatu bahasa yang di pahami oleh seseorang sehingga orang lain dapat membaca langsung lambanglambang grafik tersebut kalau mereka memahami bahasa dan gambaran grafik itu (Lado, 1979:143).

Pendapat lain menyatakan bahwa menulis adalah menuangkan gagasan, pendapat, perasaan, keinginan, dan kemauan, serta informasi ke dalam tulisan dan kemudian "mengirimkannya" kepada orang lain. Hal ini berarti menulis mengandung makna menyampaikan pikiran, perasaan, atau pertimbangan melalui tulisan (Syafi'ie, 1998:45). Sementara itu, WJS Poerwodarminto (1987:105) secara leksikal mengartikan bahwa menulis adalah melahirkan pikiran atau ide. Setiap tulisan harus mengandung makna sesuai dengan pikiran, perasaan, ide, dan emosi penulis yang disampaikan kepada pembaca untuk dipahami tepat seperti yang dimaksud penulis.

Berdasarkan beberapa pengertian yang telah diuraikan, maka dapat disimpulkan bahwa menulis adalah sebuah kegiatan yang dilakukan berasal dari pikiran, ide, dan emosi yang dilukiskan 
dalam bentuk lambang-lambang grafik yang memiliki makna, untuk menuangkan gagasan, pendapat, perasaan, keinginan, serta informasi yang disampaikan melalui Bahasa tulis, yang dapat dipahami oleh seseorang yang membacanya.

Pada prinsipnya fungsi utama dari tulisan adalah sebagai alat komunitas yang tidak langsung. Menulis sangat penting bagi pendidikan karena memudahkan para pelajar berpikir. Juga dapat menolong kita berpikir secara kritis. Memudahkan kita merasakan dan menikmati hubunganhubungan, memperdalam daya tanggap atau persepsi kita, memecahkan maslahmasalah yang kita hadapi, menyusun urutan bagi pengalaman. Tulisan dapat membantu kita menjelaskan pikiranpikiran kita. Salah satu dari tugas-tugas terpenting seorang penulis adalah menguasai prinsip-prinsip menulis dan berpikir, yang dapat menolongnya mencapai maksud dan tujuannya. Salah satu prinsip-prinsip yang paling penting yang dimaksudkan adalah penemuan, susunan, dan gaya.

Jenis tulisan menurut tujuan menulis sebagai berikut:

1. Narasi, yakni karangan/tulisan ekspositoris maupun imajinatif yang secara spesifik menyampaikan informasi tertentu berupa perbuatan/ tindakan yang terjadi dalam suatu rangkaian waktu.

2. Deskripsi, yakni karangan/tulisan yang secara spesifik menyampaikan informasi tentang situasi dan kondisi suatu lingkungan (kebendaan ataupun kemanusiaan). Penyampaiannya dilakukan secara objektif, apa adanya, dan terperinci.

3. Ekposisi, yakni karangan/tulisan yang secara spesifik menyampaikan informasi tentang sesuatu hal (faktual maupun konseptual). Penyampaiannya dilakukan dengan tujuan menjelaskan, menerangkan, dan menguraikan sesuatu hal sehingga pengetahuan pendengar/pembaca bertambah.

4. Argumentatif, yakni karangan/tulisan yang secara spesifik menyampaikan informasi tentang sesuatu hal (faktual maupun konseptual). Penyampaiannya dilakukan dengan tujuan mempengaruhi, memperjelas, dan meyakinkan.

5. Persuasif, yakni karangan/tulisan yang secara spesifik menyampaikan informasi tentang sesuatu hal (faktual maupun konseptual). Penyampaiannya dilakukan dengan tujuan mempengaruhi, meyakinkan, dan mengajak.

Setiap jenis tulisan mengandung beberapa tujuan, tetapi karena tujuan itu sangat beraneka ragam, bagi penulis yang berlum berpengalaman ada baiknya memperhatikan kategori di bawah ini:

1. Memberitahukan atau mengajar;

2. Menyakinkan atau mendesak;

3. Menghibur atau menyenangkan;

4. Mengutarakan/mendeskripsikan presaan dan emosi yang berapi-api.

Sehubungan dengan "tujuan" penulisan sesuatu tulisan, Hugo Hartig merangkumkannya sebagai berikut:

a. Tujuan penugasan, penulis menulis sesuatu karena ditugaskan bukan atas kemauannya sendiri.

b. Tujuan altruistik, penulis bertujuan untuk menyenangkan para pembaca.

c. Tujuan persuasif, yaitu menyakinkan para pembaca akan kebenaran gagasan yang diutarakan.

d. Tujuan informasional, yaitu memberi informasi atau keterangan penerangan kepada para pembaca.

e. Tujuan pernyataan diri, yaitu memperkenalkan atau menyatakan diri sang pengarang kepada para pembaca. 
f. Tujuan kreatif, yaitu tulisan yang bertujuan untuk mencapai nilai-nilai artistik, nilai-nilai kesenian.

g. Tujuan pemecahan masalah.

\section{Karangan Deskripsi}

Paragraf deskripsi merupakan salah satu jenis komunikasi tertulis yang menggambarkan atau menuliskan suatu objek secara detail atau mendalam sesuai dengan keadaan yang sebenar-benarnya tentang objek yang dilukiskan tersebut. Segala sesuatu yang didengar, dicium, dilihat, dan dirasa melalui alat-alat sensori, yang selanjutnya dengan media kata-kata, hal tersebut dilukiskan agar dapat dihayati oleh orang lain

Kata deskripsi berasal dari bahasa latin, yaitu describere yang berarti menulis tentang, membeberkan (memerikan), melukiskan sesuatu hal. Dalam bahasa Inggris adalah description yang tentu saja berhubungan dengan kata kerja to describe (melukiskan dengan bahasa) (Lamuddin Finozza, 2009: 239-240). Dalam kamus bahasa Inggris kata deskripsi adalah describe dan description. Describe yang berarti melukiskan; menggambarkan; membuat; sedangkan description yakni gambaran; lukisan. Describe lebih mengarah kepada penjelasan sebagai kata kerja, sedangkan description lebih sebagai kata benda.

Menurut Slamet (2008:103), mengungkapkan bahwa "deskripsi (pemerian) adalah wacana yang melukiskan atau menggambarkan sesuatu berdasarkan kesan-kesan dari pengamatan, pengalaman, dan perasaan penulisnya. Sasaran yang dituju yakni menciptakan atau memungkinkan terciptanya daya imajinasi (daya khayal) pembaca sehingga ia seolah-olah melihat, mengalami, dan merasakan sendiri apa yang dialami oleh pembuat wacana. Disini penulis berusaha memindahkan kesan-kesan hasil pengamatan dan perasaannya kepada pembaca dengan membeberkan sifat dan semua perincian yang ada pada sebuah objek ke dalam wacana deskripsi. Oleh karena itu, menulis karangan deskripsi dapat dikatakan lebih menekankan pada dimensi ruang".

Hal senada dikemukakan oleh Syamsuddin, dkk (2007:81) bahwa "paragraf deskripsi bertujuan menggambarkan suatu benda, tempat, keadaan, atau perististiwa tertentu dengan kata-kata. Misalnya menggambarkan objek berupa benda atau orang, digambarkan seolah-olah merasakan, menikmati, atau merasa menjadi bagiannya. Semuanya digambarkan dengan terperinci. Pendapat lain mengemukakan bahwa karangan deskripsi adalah karangan yang berisi gambaran mengenai suatu hal ataupun keadaan tertentu sehingga pembaca seolaholah melihat, mendengar, atau merasakan hal tersebut".

Dari uraian di atas dapat disimpulkan bahwa karangan deskripsi adalah karangan yang menggambarkan suatu objek atau tempat kepada pembaca sehingga pembaca seolah-olah mserasakan, mengalami, melihat kejadian atau hal-hal yang dituliskan oleh pengarang.

\section{Tujuan Menulis Karangan Deskripsi}

Tujuan yang ingin dicapai oleh paragraf ini adalah tercapainya penghayatan agar imajinatif terhadap sesuatu sehingga pendengar atau pembaca merasakan seolah-olah ia sendiri yang mengalami dan mengetahui secara langsung. Oleh karena itu, untuk menulis paragraf deskripsi erat kaitannya dengan 
pengetahuan yang dimiliki oleh siswa dan kondisi lingkungan belajar yang kondusif.

Tarigan (1983:50) berpendapat bahwa "tujuan menulis karangan deskripsi adalah mengajak para pembaca bersamasama menikmati, merasakan, memahami dengan sebaik-baiknya beberapa objek (sasaran, maksud), adegan, kegiatan (aktivitas), orang (pribadi, oknum), atau suasana hati (mood) yang telah dialami oleh seseorang yang sedang menulis. Sebuah wacana yang utuh dapat dibagibagi berdasarkan tujuan umum yang tersirat dibalik wacana tadi. Penulis tersebut pengungkapannya lebih mendekat kepada pembaca, terungkap kesan penulis dalam mengamati dan merasakan suatu objek, sehingga pembaca merasa menikmati, dan merasakan sesuatu secara nyata seperti yang dialami penulis".

Proses menulis karangan deskripsi seseorang akan memindahkan kesankesannya, memindahkan hasil pengamatan dan perasaannya kepada para pembaca. Sasaran yang ingin dicapai oleh seorang penulis deskripsi adalah menciptakan atau memungkinkan terciptanya daya khayal (imajinasi) kepada para pembaca, seolaholah Ia melihat sendiri objek tadi secara keseluruhan bagaimana yang dialami secara fisik oleh penulisnya (Keraf, 1985:93).

Dengan cara ini memenuhi pula kebutuhan para pendengar atau pembacanya untuk memperoleh informasi tentang kejadian itu. Menurut Wiyanto (2004:64), tujuan menulis deskripsi adalah untuk memberi kesan kepada pembaca terhadap suatu tempat, kejadian, dan menggambarkan sesuatu hal atau peristiwa. Dari pendapat Wiyanto menunjukan tujuan deskripsi adalah mengungkapkan bahasa ke dalam tulisan yang berupa imajinasi atau khayalan dengan tujuan agar pembaca membayangkan suasana dan peristiwa, sehingga pembaca memahami suatu sensasi atau emosi yang disampaikan penulisnya.

Menurut Yusi Rosdiana, dkk (2008: 3.21) menyatakan bahwa "menulis deskripsi bertujuan membuat para pembaca menyadari dengan hidup apa yang diserap penulis melalui pancaindera, merangsang perasaan pembaca mengenai apa yang digambarkannya, menyajikan suatu kualitas pengalaman langsung. Objek yang dideskripsikan mungkin sesuatu yang bisa ditangkap dengan pancaindera kita, sebuah pemandangan alam, jalan-jalan kota, tikus-tikus selokan atau kuda balapan, wajah seseorang yang cantik, atau seseorang yang putus asa, alunan musik atau gelegar guntur, dan sebagainya". Sedangkan menurut M. Atar Semi (2007: 66) bahwa "menulis deskripsi bertujuan untuk memberikan rincian atau detil tentang suatu objek, sehingga dapat memberi pengaruh pada emosi dan menciptakan imajinasi pembaca bagaikan melihat, mendengar, atau merasakan langsung apa yang disampaikan penulis".

Berdasarkan pemaparan tentang tujuan menulis deskripsi di atas, bahwa dalam menulis karangan deskripsi pembaca diharapkan akan terbawa oleh sesuatu yang dirasakan, dialami oleh penulis dengan begitu keduanya seolah terbawa dalam satu tempat maupun suasana yang sama.

\section{Ciri Paragraf Deskripsi}

Penggambaran sesuatu dalam karangan deskripsi memerlukan kecermatan pengamatan dan ketelitian. Untuk bisa mengembangkan suatu objek melalui rangkaian kata-kata yang penuh arti sehingga pembaca dapat 
memahaminya seolah-olah melihat, mendengar, merasakan, maupun menikmati sendiri objek itu maka kita perlu untuk memahami ciri-ciri dari karangan deskripsi tersebut.

Menurut M. Atar Semi (2007: 66) terdapat lima ciri-ciri dari menulis karangan deskripsi yaitu:

a) Karangan deskripsi memperlihatkan detail atau rincian tentang objek.

b) Karangan deskripsi lebih bersifat mempengaruhi emosi dan membentuk imajinasi pembaca.

c) Karangan deskripsi umumnya menyangkut objek yang dapat di indera oleh pancaindera sehingga objeknya pada umumnya berupa benda, alam, warna, dan manusia.

d) Penyampaian karangan deskripsi dengan gaya memikat dan dengan pilihan kata yang menggugah.

e) Organisasi penyajian lebih umum menggunakan susunan ruang.

Dari berbagai pendapat di atas dapat disimpulkan bahwa tujuan menulis karangan deskripsi pada penelitian ini adalah daya inisiatif dan kreatif serta mendorong siswa agar lebih tertarik dalam menulis. Menulis yang dimaksud di sini adalah menulis karangan deskripsi yang disampaikan oleh guru. Menulis karangan deskripsi mempunyai tujuan yang khusus seperti menginformasikan, melukiskan, dan meyarankan. Tujuan menulis deskripsi adalah memproyeksikan sesuatu mengenai suatu hal kedalam sepenggal tulisan. Penulis memegang suatu peranan tertentu, dalam tulisan mengandung nada yang sesuai dengan maksud dan tujuan.

\section{Struktur Teks Deskripsi}

Struktur teks deskripsi terdiri atas identifikasi dan deskripsi. Hal tersebut dinyatakan Gerot dan Peter (1995:208), bahwa "the generic structure of descriptive text are identification (identifies phenomenon to be described) and description (describes parts, qualities, characteristics)". Berbeda dengan Gerot dan Peter, Kemendikbud (2013:36) menyatakan bahwa teks tanggapan deskriptif memiliki tiga bagian, yaitu identifikasi, klasifikasi (penggolongan)/ definisi, dan deskripsi bagian. Kemendikbud (2014:45) di dalam buku pegangan siswa SMP kelas VII menyatakan bahwa "struktur teks deskripsi terdapat dua bagian, yaitu deskripsi umum dan deskripsi bagian".

Dalam buku Kemendikbud pegangan siswa dan guru edisi revisi 2014 pada materi Bab II dilakukan penggantian nama dan struktur teks. Pada edisi pertama nama teks adalah teks tanggapan deskriptif dengan struktur identifikasi, klasifikasi/ definisi, dan deskripsi bagian, sedangkan pada edisi revisi 2014 nama teks adalah teks deskripsi dengan struktur deskripsi umum dan deskripsi bagian. Memang terdapat perbedaan pendapat mengenai struktur teks deskripsi, tetapi pada dasarnya sama saja. Hal tersebut disebabkan jika dianalisis lebih mendalam maka akan diperoleh kesamaan dari kedua pendapat tersebut.

Struktur yang pertama dari Gerot dan Peter adalah identifikasi, sedangkan Kemdikbud deskripsi umum. Walau namanya berbeda tetapi hal yang dibahas sama, yaitu sama-sama membahas objek secara umum. Struktur yang kedua memang berbeda, yaitu pendapat Gerot dan Peter adalah deskripsi dan Kemdikbud deskripsi bagian. Hal ini sama saja karena keduanya membahas tentang bagian dari objek yang dideskripsikan, yaitu dapat berupa bagian-bagian dari objek, kualitas, 
atau karakteristik. Berikut ini penjabaran dua bagian teks deskripsi.

a. Deskripsi umum, dalam teks deskripsi berkaitan dengan penetapan ciri-ciri secara universal dari hal yang dideskripsikan. Objek yang dideskripsikan diinterpretasikan dari sudut pandang di luar objek tersebut. Hal tersebut dapat didasarkan pada kedudukan, sejarah, wilayah, manfaat, dan kandungan dari objek.

b. Deskripsi bagian, adalah pemaparan secara terperinci dari bagian-bagian yang dipaparkan. Objek yang menjadi kajian dideskripsikan lagi secara lebih terperinci dari bagian-bagiannya. Pemaparan dilakukan pada pembagian yang lebih khusus lagi dari objek yang dideskripsikan atau memaparkan hal yang lebih khusus dari komponen penyusun objek yang dideskripsikan.

\section{Langkah Menulis Karangan Deskripsi}

Paragraf yang baik harus memenuhi tiga syarat, yaitu (1) kesatuan, (2) koherensi, dan (3) pengembangan. Sebuah paragraf memenuhi kesatuan yang baik jika semua kalimat yang membangunnya hanya menyatakan satu pikiran/gagasan pokok (satu ide, satu tema). Koherensi ialah kepaduan/ kekompakan hubungan antara kalimat yang satu dengan kalimat yang lain. Pengembangan ialah rincian pikiran pokok ke dalam pikiran-pikiran penjelas dan pengurutannya secara teratur (Soedjito, 1986:30).

Menurut Brian (2011) langkah menyusun paragraf deskripsi meliputi:

1) Menemukan tema, kegiatan mula-mula dilakukan jika akan menulis suatu karangan adalah menentukan tema. Hal ini bahwa berarti harus ditentukan apa yang akan dibahas dalam tulisan.
2) Menetapkan tujuan penulisan, setiap penulis harus mengungkapkan dengan jelas tujuan penulisan yang akan dilaksanakannya. Perumusan tujuan penulisan sangat penting dan harus ditentukan lebih dahulu karena hal ini merupakan titik tolak dalam seluruh kegiatan menulis selanjutnya.

3) Pengumpulan bahan, pada waktu pemilihan dan membatasi topik kita hendaknya sudah memperkirakan kemungkinan mendapatkan bahan. Dengan membatasi topik, maka telah memusatkan perhatian pada topik yang terbatas itu, serta mengumpulkan bahan yang khusus pula.

4) Membuat kerangka karangan, agar dapat menentukan organisasi pengarang, sebelumnya kita harus menyusun kerangka karangan merupakan satu cara untuk menyusun suatu rangkaian yang jelas dan terstruktur yang teratur dari karangan yang akan ditulis.

5) Mengembangkan kerangka karangan, langkah selanjutnya setelah menyusun kerangka karangan adalah mengembangkan kerangka karangan menjadi suatu karangan yang utuh.

6) Merefleksi karangan, pada langkah merefleksi dilakukan penulisan secara menyeluruh mengenai ejaan, tanda baca, pilihan kata, dan sebagainya.

\section{Penilaian Menulis Karangan Deskripsi}

Penilaian adalah suatu proses untuk mengukur kadar pencapaian tujuan atau tingkat keberhasilan (Nurgiyanto, 1988:5). Keberhasilan yang akan dinilai dalam menulis karangan deskripsi karangan dapat dilihat dari berbagai aspek diantaranya: isi gagasan yang dikemukakan, organisasi isi, 
tata bahasa, ejaan, gaya; pilihan struktur dan kosakata.

Dalam keterangan di atas, maka dapat disimpulkan bahwa aspek-aspek yang akan dinilai dalam menulis karangan deskripsi adalah: (1) kesesuaian antara judul dengan isi, (2) pemilihan kata atau diksi, (3) ejaan dan tanda baca, (4) kohesi dan koherensi, (5) kerapian tulisan, (6) keterlibatan pancaindera, (7) imajinasi, (8) memusatkan pada objek yang ditulis, (9) kesan hidup, dan (10) menunjukkan objek yang ditulis.

Penilaian yang digunakan dalam penelitian ini dilakukan secara terpadu dalam kegiatan belajar mengajar. Penilaian dilakukan dengan mengumpulkan hasil kerjanya. Penilaian dihasilkan dari penilaian proses dan penilaian hasil. Penilaian proses dilakukan pada saat pembelajaran berlangsung, yaitu menilai perilaku siswa terhadap pembelajaran menulis karangan deskripsi yang meliputi keaktifan siswa dan keseriusan siswa dalam menulis karangan deskripsi. Penilaian hasil diperoleh dari hasil penilaian menulis karangan deskripsi yang berpedoman pada aspek penilaian karangan deskripsi.

Penilaian pembelajaran Bahasa Indonesia dilaksanakan secara holistik, artinya pelaksanaan penilaian itu secara menyeluruh, bukan hanya pada tiap-tiap aspek pelajarannya saja. Dalam pembelajaran bahasa penilaian merupakan hal yang sangat penting. Menurut Burhan Nurgiantoro (2001:4), hal ini bertujuan untuk mengukur kadar pencapaian tujuan.

$$
\text { Penilaian menulis deskripsi }
$$
mencakup berbagai macam aspek. Burhan Nurgiyantoro (2001:306) menyatakan "aspek menulis meliputi isi, organisasi, kosakata, penggunaan bahasa, dan mekanik".

\section{Media Gambar dalam Pembelajaran}

Kata media berasal dari bahasa latin yaitu jamak dari kata medium yang secara harfiah berarti perantara atau pengantar. Media pembelajaran adalah segala sesuatu yang dapat digunakan untuk menyalurkan pesan (bahan pembelajaran) sehingga dapat merangsang perhatian, minat pikiran, dan perasaan pembelajar (siswa) dalam kegiatan belajar untuk mencapai tujuan pembelajaran tertentu.

Media pembelajaran memiliki fungsi yang sangat penting yaitu sebagai pembawa informasi dan pencegah terjadinya hambatan proses pembelajaran, sehingga informasi atau pesan dari komunikator dapat sampai kepada komunikan secara efektif dan efesien. Selain itu, media pembelajaran merupakan unsur atau komponen sistem pembelajaran maka media pembelajaran merupakan media integral dari pembelajaran.

Bentuk umun dari media gambar terangkum dalam pengertian dari media grafis. Karena media gambar merupakan bagian dari pembuatan media grafis. Sebelum kita nengetahui lebih lanjut mengenai media gambar ada baiknya kita mengetahui lebih dahulu pengertian dari media grafis.

Menurut I Made Tegeh (2008), media grafis atau graphic material adalah suatu media visual yang menggunakan titik-titik, garis-garis, gambar-gambar, tulisan, atau symbol visual yang lain dengan maksud untuk menikthisarkan, menggambarkan, dan merangkum suatu ide, data kejadian. Batasan tersebut member gambaran bahwa media grafis merupakan media dua dimensi yang dapat dinikmati dengan menggunakan indra penglihatan. 
Media grafis dapat mengomunikasikan fakta dan gagsangagasan secara jelas dan kuat melalui perpaduan antara pengungkapan kata-kata dan gambar. Pengungkapan itu bias berupa diagram, sket, atau grafik. Kata-kata dan angka-angka dipergunakan sebagai judul dan penjelasan, sedangkan sket, lambang dan bahkan foto dipergunakan untuk mengartikan fakta, pengertian, dan gagagsan yang pada hakikatnya penyampai presentasi grafis.

Dari pengertian media grafis di atas kita dapat mengambil kesimpulan bahwa memang benar media gambra merupakan bagian yang utuh dari media grafis tersebut karena pada dasarnya media gambar merupakan kumpulan dari beberapa titik dan garis yang memvisualisasikan gambar sebuah benda atau seorang tokoh yang dapat memperjelas kita dalam memahami benda atau tokoh tersebut.

Dalam pembelajaran di sekolah dasar media gambar sangat baik di gunakan dan di terapkan dalam proses belajar mengajar sebagai media pembelajaran karena media gambar ini cenderung sangat menarik hati siswa sehingga akan muncul motivasi untuk lebih ingin menegtahui tentang gambar yang dijelaskan dan gurupun dapat menyampaikan materi dengan optimal melalui media gambar tersebut. Belajar melalui media ini lebih lama disimpan dalam memori.

Kelebihan media gambar antara lain:

1. Sifatnya konkrit. Gambar/ foto lebih realistis menunjukkan pokok masalah disbanding dengan media verbal semata.

2. Gambar dapat mengatasai masalah batasan ruang dan waktu. Tidak semua benda, objek atau peristiwa dapat dibawa ke kelas, dan tidak selalu bisa, anak-anak dibawa ke objek tersebut.

3. Media gambar dapat mengatasi keterbatasan pengamatan kita.

4. Dapat memperjelas suatu masalah, dalam bidang apa saja dan untuk tingkat usia beberapa saja, sehingga dapat mencegah atau membetulkan kesalahpahaman.

5. Murah harganya, mudah didapat, mudah digunakan, tanpa memerlukan peralatan yang khusus.

Selanjutnya, kekurangan media gambar antara lain:

1. Penghayatan tentang materi kurang sempurna, karena media gambar hanya menampilkan persepsi indera mata yang tidak cukup kuat untuk menggerakkan seluruh kepribadian manusia, sehingga materi yang akan dibahas kurang sempurna.

2. Gambar atau foto benda yang terlalu kompleks kurang efektif untuk kegiatan pembelajaran.

3. Ukuran sangat terbatas untuk kelompok besar.

\section{Jenis-Jenis Media Gambar dalam Pembelajaran}

Media gambar dalam pembelajaran menggunakan gambar dapat disajikan dalam bentuk: (1) poster; (2) kartun; (3) komik; (4) gambar fotografi; (5) slide; (6) bagan; dan (7) diagram.

\section{Poster}

Poster adalah media pembelajaran berbentuk ilustrasi gambar yang disederhanakan, dibuat dengan ukuran besar, bertujuan menarik perhatian, dan isi atau kandungannya berupa bujukan, memotivasi, atau mengingatkan suatu gagasan pokok, fakta atau peristiwa 
tertentu. Gagasan tadi disampaikan dengan kata-kata singkat namun padat dan jelas.

\section{Kartun}

Kartun merupakan sebuah media unik untuk mengemukakan gagasan. Kartun dapat digunakan sebagai media pembelajaran karena dapat dipakai untuk memotivasi siswa dan memberikan ilustrasi secara komunikatif.Kartun dibuat dalam bentuk lukisan atau karikatur.

\section{Komik}

Komik adalah media pembelajaran berbentuk gambar selain kartun yang juga bersifat unik.Bedanya, pada komik terdapat karakter yang memerankan suatu cerita dalam urutan (rangkaian seri).Komik memiliki keunggulan tersendiri sebagai media pembelajaran dalam bentuk gambar, karena komik sangat akrab dengan keseharian siswa.

\section{Gambar Fotografi}

Gambar fotografi merupakan media pembelajaran yang sangat mudah dibuat pada era digital sekarang ini. Berbagai macam gadget yang ada di sekitar kita biasanya dilengkapi dengan fitur kamera yang memungkinkan kita membuat gambar fotografi.Gambar fotografi karena langsung berisi foto nyata objek atau situasi atau peristiwa, maka ia merupakan media pembelajaran gambar yang sangat realistik (konkret).

\section{Bagan}

Bagan adalah kombinasi media grafis dan foto yang dirancang untuk memvisualisasikan suatu fakta pokok atau gagasan dengan cara yang logis dan teratur.Fungsi utama bagan sebagai media gambar adalah untuk memperlihatkan hubungan, perbandingan, jumlah relatif, perkembangan, proses, klasifikasi, dan organisasi.

\section{Diagram}

Diagram adalah gambar yang digunakan untuk media pembelajaran dalam bentuk gambaran sederhana yang dibuat dengan tujuan memperlihatkan bagian-bagian, atau hubungan timbal balik, biasanya dengan menggunakan garus-garis dan keterangan bagian atau hubungan yang ingin ditunjukkan.

\section{Grafik}

Grafik adalah media gambar untuk tujuan penyajian data berupa angka-angka. Grafik memberikan informasi inti suatu data, berupa hubungan antar bagian-bagian data. Adabermacam-macam bentuk media gambar grafik yang dapat disajikan sebagai media pembelajaran kepada siswa, misalnya grafik garis, grafik batang, grafik lingkaran, dan grafik bergambar. Setiap jenis grafik mempunyai kekhususan dalam hal jenis data yang ditampilkan.

\section{KESIMPULAN}

Menulis merupakan suatu keterampilan berbahasa yang digunakan untuk berkomunikasi secara tidak langsung, tidak secara tatap muka dengan orang lain. Menulis merupakan suatu kegiatan yang produktif dan ekspresif. Pendidikan sangat memerlukan tulisan sebagai hasil menulis karena menulis dapat berperan untuk mempermudah pelajar berpikir kritis agar dapat meningkatkan kemanpuan menulis.

Salah satu contoh menulis adalah menulis karangan deskriptif. Siswa dianjurkan menggambarkan suatu objek yang dilihatnya secara langsung, karangan deskripsi merupakan cara mudah memulai menulis karena pola pikir akan diolah dan dilatih menuangkan kata-kata sesuai apa yang kita lihat, tanpa harus berpikir kritis membayangkan yang ingin ditulisnya. 
Secara garis besar, karangan deskripsi terdapat dua macam, yang pertama deskripsi ekspositoris yaitu karangan yang bertujuan untuk memaparkan, menjelaskan informasi yang dibuat dalam bentuk paragraf agar pembaca dapat melihat, merasakan apa yang dideskripsikan, yang kedua deskripsi impresionistik yaitu gambaran tentang sesuatu berdasarkan pada pemahaman subjektif seseorang. Di sinilah pentingnya seorang guru memilih media dalam proses pembelajaran guna mengembangkan kemampuan menulis siswa.

Adapun media pembelajaran yang cocok dengan karangan deskripsi yaitu dengan menggunakan media gambar. Perlu kita ketahui bahwa di era modern ini, siswa lebih gemar melihat gambar dibandingkan dengan yang lainnya. Gambar pada dasarnya membantu mendorong para siswa dan dapat membangkitkan minatnya pada pelajaran. Membantu mereka dalam kemanpuan berbahasa, kegiatan seni dan pernyataan kreatif dalam bercerita. Media gambar adalah segala sesuatu yang diwujudkan secara visual kedalam bentuk dua dimensi sebagai curahan atau pikiran yang bermacam-macam seperti lukisan.

\section{DAFTAR PUSTAKA}

Darmawan, Deni. 2015. Kosmunikasi Pendidikan Perspektif Bio-Komunikasi. Bandung: PT Remaja Rosdakarya.

Dalman. 2016. Keterampilan Menulis. Jakarta: PT Raja Grafindo.

Dalman. 2015. Penulisan Populer. Jakarta: PT Raja Grafindo

Donny, Michael. 2013. Penggunaan Media Gambar dalam Proses Pembelajaran. (Online, http://pendas2013.blogspot.com/2013/01/penggunaan-media-gambar-dalam-proses. html, Diakses 29 Desember 2018).

Ghazali, Syukur. 2010. Pembelajaran Keterampilan Berbahasa. Bandung: PT Refika Aditama.

Mansyur, Umar. 2016. Inovasi Pembelajaran Bahasa Indonesia melalui Pendekatan Proses. Retorika: Jurnal Bahasa, Sastra, dan Pengajarannya, 9(2), 158-163. https://doi.org/10.26858/retorika.v9i2.3806

Mansyur, Umar. 2018. Pembelajaran Inovatif Bahasa Indonesia di Sekolah Dasar. INA-Rxiv. https://doi.org/10.31227/osf.io/fyr8g

Nurhibatullah, 2015. Makalah Keterampilan Menulis. (Online), https://nurhibatullah.blog spot.com/2015/12/makalah-keterampilan-menulis.html, Diakse 27 Desesmber 2018).

Susanto, Hadi. 2015. Keterampilan Menulis Paragraf Deskripsi. (Online, (https://bagawanabiyasa.wordpress.com/2015/12/14/keterampilan-menulis-paragrafdeskripsi/, Diakses 29 Desember 2018).

Sumantri, Mohamad Syarif. 2015. Strategi Pembelajaran. Jakarta: PT RajaGrafindo Persada. Sanjaya, Wina. 2012. Media Komunikasi Pembelajaran. Bandung: Prenadamedia Group.

Suprihatiningrum, Jamil. 2012. Strategi Pembelajaran Teori dan Aplikasi. Yogyakarta: ArRuzz Media.

Sritopia. 2017. Pengertian Paragraf Deskripsi Lengkap dengan Jenis, Tujuan, dan Cara Mengerjakan. (Online, https://quipper.com/id/blog/un/bahasa-indonesia-un-sma/ pengertian-paragraf-deskripsi-lengkap-dengan-jenis-tujuan-dan-cara-mengerjakan, Diakses 7 Januari 2019).

Tarigan, Henry Guntur. 2008. Menulis Sebagai Suatu Keterampilan B erbahasa. Bandung: Angkasa Bandung. 